А.Шептицький, переступаючи архієрейські пороги, наголошував, що «справа українська - це своя справа». «Така була політика новітнього владики супроти свого народу й цілої української нації, - підкреслював К.Левицький. - Тому заслужив він собі у нас назву найбільшого українського громадянина» [Левицький К. Українські політики. Сильвети наших давніх послів і політичних діячів 1907-1914 pp.- С. 25].

Оскільки парламентська діяльність А.Шептицького здійснювалася в руслі прагнень, спрямувань та орієнтирів українського політичного проводу, то є підстави стверджувати, що митрополит на державному рівні виступив виразником інтересів українського політичного табору.

Н.Мадей* (м. Львів)

\title{
ВЕЛЕГРАДСЬКІ З’ӞЗДИ
}

Прагнення до єдності між християнами, назване популярним сьогодні терміном «екуменізм», має свої витоки. Розкол між візантійською та католицькою церквами остаточно утвердився в свідомості звичайних людей після хрестових походів та взяття хрестоносцями Константинополя у 1204 році. Наступні століття були позначені змаганнями до єдності, але ініціатором цих змагань виступала римо-католицька церква. У католицькій теології всі церкви, які не були під папською юрисдикцією, вважались об'єктами місіонерської діяльності. Результатом такої місійно-унійної діяльності було поглиблення розколу між католицькою та східними церквами. Сегменти останніх проголосили єдність 3 Римом, розпочавши своє існування як уніатські церкви.

3 часом римо-католицька ієрархія усвідомила всі вади та похибки уніатизму. Початок XX століття - це початок зміни стереотипів поєднання між церквами. Законним видалось питання: яке місце в новій унійній політиці Риму мають посідати уніатські церкви? Практикуються Велеградські з'їзди, які були спробою представників східних католицьких церков активно включитись у християнський екуменічний рух. Зібрання

\footnotetext{
* Мадей Н.М. - кандидат історичних наук, асистент кафедри теорії та історії культури Львівського національного університету імені Івана Франка.
} 
у Велеграді відбувались у двох формах: наради окремих представників уніатського кліру (1913, 1921, 1922 роки) або організаційно оформлені конгреси (з'їзди) з численними делегаціями від католицької, уніатської та православної сторін. Спроба ця не мала успіху, а самі з'їзди були віддзеркаленням тогочасних політичних реалій.

Місцем проведення з'їздів було обрано місто Велеград. Цей вибір був достатньо символічним: саме в столиці Великоморавської держави розпочали свою проповідницьку діяльність Солунські брати - Кирило i Мефодій. Саме від них веде свій родовід слов'янська писемність, віра i обрядовість. Розпочати нове навернення слов'ян (православних»схизматиків», за тодішньою термінологією) або принаймні «промостити дорогу до нав'язання відносин між католицькими слов'янами і великим православним Сходом» [Конгрес на Велеграді // Нива.- 1907.- № 9.- С. 498] - саме такі завдання планувалось вирішити на I Велеградському 3'їзді. Ініціаторами скликання з'їзду були морав'яни та чехи, а саме: д-р Антін Стоян, парох в Дражовичах на Моравії, посол до державної думи та сойму, відомий моравський діяч, i д-p Антін Подгаля, митрополитальний крилошанин у Празі. Засідання з'їзду, який відбувся 24-27 липня 1907 року, проходили у Велеградському монастирі о.о. Єзуїтів. На з'їзд прибуло близько сотні учасників, які репрезентували всі слов'янські народи. 3 вищої ієрархії були присутні митрополит Шептицький, празький архієпископ Вебер та Меніньї - архієпископ софійський. Більшість слов'янського єпископату обмежилось надсиланням привітальних листів. Цікавим $є$ той факт, що всі наради відбувались латинською мовою. Докладні стенограми опубліковані в «Lidovych novinach». Якщо не зупинятись на подробицях кожного виступу, то загалом дискусії були присвячені одній проблемі - «винайти спосіб, який міг би привести до сполуки церкви православної 3 католицькою». У рефератах йшлося і про методи діяльності супроти Російської православної церкви (о. Урбан), і про стан російського богослов'я (о. Пальмірі), про історію руського православ'я (д-р Грівец) та його обрядові особливості (о. Галущинський). Допускались виступаючі і типових (для тодішньої католицької теології) помилок, як-от «прийняття русинами християнства в сполуці з Римською церквою [Там само.- С. 599] чи твердження, що «правдивою наукою Христовою «є тільки наука католицької церкви» [Там само.- С. 597]. Для реалізації поставленої з’їдом мети було створено щомісячник «Slavorum litterae theologicae» та апостольство Кирила та Мефодія. У руслі промов на з'їзді були прийняті відповідні постанови: 1. «Про всі спірні питання належить помістити в Slavorum litteris theologicis якнайосновніші розвідки». 2. «...просити 
православних богословів, щоби свою науку про спірні питання оголосили у своїх наукових видавництвах» [Там само.- С. 601]. На думку учасників 3'їзду, такий науковий обмін думками повинен спричинити полеміку, яка могла б 3 часом призвести до якогось консенсусу. Для кращого ознайомлення обох сторін (католицької i православної) планували інтенсивніше здійснювати переклади - як православної, так і католицької літератури; пропонували нав'язати особисті стосунки 3 російськими богословами (п.6), в рамках освітньої діяльності передбачали відвідування католицькими теологами православних богословських факультетів (п.7), створення кафедр історії православного віросповідання в католицьких університетах (п.11). Окрім того, планували продовжити консолідацію зусиль усіх слов'ян-католиків й у 1908 році скликати з цією метою з'їзди окремих слов'янських народів, а через 2 роки (1909 року) знову організувати з'їзд у Велеграді.

Другий Велеградський з'їзд (31 липня - 3 серпня 1909) значно відрізнявся від попереднього. Перш за все кількістю делегатів (близько 200) та якісним складом - якщо в 1907 році учасниками з'їзду було 80 слов'ян-католиків, двоє італійців та німців, то на другому з'їзді були присутні і представники Російської православної церкви (протоієрей Алексій Мальцев, настоятель посольської церкви в Берліні, та його супутник Василь Гекен). Обом петербурзький митрополит Антоній дав благословення і дозвіл на участь у з'їзді. У звіті про з'їзд на сторінках «Ниви» детально перераховані найвидатніші делегати - представники різних національностей. Причиною такої уваги було перш за все те, що місцевий архієпископ оломоуцький екзарх Фр.С.Бауер взяв над ним протекторат, відкрив засідання і відвідував їх. Очолював конгрес митрополит А.Шептицький, його помічниками були д-р Стоян, о. Яшек (катихит) i єзуїт Шпельдак 3 Праги. Відрізнявся другий 3'їзд від попереднього і кращою організацією: відбувались і пленарні засідання, $\mathrm{i}$ секційні; секцій було чотири: східна, західна, теоретична і практична. Одночасно $з$ конгресом уніоністів відбувались: у перший день - загальні збори апостольства Кирила і Мефодія, загальні збори католицького союзу вчителів; на другий і третій день - збори богословів і академіків. Така паралельність надавала зборам більшої ваги, але одночасно порушувала спокійний хід роботи конгресу.

На пленарному засіданні найбільш виваженим був виступ митрополита А.Шептицького. Він подав короткий огляд кириломефодіївського руху від першого з'їзду, його практичні досягнення: окремі з'їзди Словенців, Хорватів і Болгар в Загребі, початок видавництва «Велеградського вісника» в Празі, співпрацю 3 православними 
богословами. «Ціллю нашого руху є, щоб ми близше пізналися, всякий прозелітизм і всяка політика є виключена. Нашою задачею є вглубитися в науку історії Церкви, догм і обрядів, вглянути в далеку минувшину і теперішність, зрозуміти себе, шанувати себе, вирівнувати непорозуміння і так споювати, лучити то, що невзгоди минувших часів розлучили». [Д-р О.Б. Другий велеградский з'їзд // Нива.- 1909.- № 10.- С. 691].

Решту наукових рефератів на пленарному засіданні можна дещо умовно поділити на дві групи: історичні екскурси в минуле церкви (причому, неодмінно з метою знайти там підтвердження католицьких догматів) о. Жіже, д-ра Штрауб, о. Буковскі, та доповіді, що стосувались РПЦ - о. Салявіль, проф. Грасіє (моральний елемент в філософії проф. Хомілкова), проф. Здзєховскі (російські філософи і питання віри), д-р Рішіг (діяльність Володимира Соловйова). Завершальною була промова о. Кончара з Сараєва «Перешкоди для злуки Сходу з Заходом». Однак як на першому, так і на другому конгресі більше практичної ваги та інтересу мали дебати в так званих комісіях або секціях. Секції мали розглянути питання, запропоновані конгресові ще перед його відкриттям, а саме: а) запровадження григоріанського календаря у східних слов'ян; б) догматичні дефініції взяття до неба Пресвятої Діви; в) заснування академії латино-слов'янської. 3 огляду на те, що нових проблем ніхто не пропонував до обговорення, питання секції теоретичної припали секціям західній і східній, а секція практична зайнялася справою заснування академії.

Секція західна обмежила коло своїх дискусій до трьох питань: метод обговорення суперечливих питань між православними i католиками, взаємні стосунки обох обрядів та запровадження практик одного обряду до другого. Власне, це останне питання викликало бурхливі суперечки, про які свідчить запропонована постанова: «З огляду на незчислимі приміри систематичного ігноровання, а навіть давлення церкви греко-католицької зі сторони клиру латинського, що діє ся, як здає ся, не без відома римських властий, з виїмкою св.Отця, з'їзд звертаєся до Римського престола, щоби він повагою своєю зволив усунути сей згіршаючий брак християнської любови» [Там само.- С. 780]. Що-правда, в кінцевому результаті була прийнята більш виважена пропозиція: «обряд має ся точно заховувати у всіх східних єпархіях, але дух церкви вселенської треба приймати» [Там само.- С. 782] - саме такий варіант запропонував А.Шептицьким і відредагував о. Пальмірі.

Найцікавішим моментом в роботі східної секції був виступ протоієрея Мальцева на тему догматів непорочного зачаття і папської непомильності в справах віри. Вперше представник православних здійснив спробу об’єктивно проаналізувати особливості католицьких 
догматів. Решта виступів звелася до обговорення практичних моментів співіснування двох гілок християнства - навчання православної молоді в католицьких університетах, студіювання церковної історії, взаємодія обох церков тощо.

Секція практична займалася справою заснування Велеградської академії. Ініціатором такого почину був словенець о. Грівец. Згідно з його пропозицією, академія мала бути міжнародним науковим товариством, метою якого є: а) піднесення і організація богословської науки у слов'янкатоликів; б) дослідження східного церковного питання; в) студії кириломефодіївські. Існування такої академії мало б підтримувати справу унії. В результаті обговорень було вирішено, що академія існуватиме як наукове товариство; складатиметься 3 трьох секцій - східної, західної і велеградської; члени будуть: звичайні, допоміжні і почесні; основні завдання - видавництво книг і джерел, роздача авторських премій, підтримка студій, досліджень, наукових подорожей. У підпорядкування академії переходило «Slavorum litterae theologicae», планувалось заснувати уніоністичну бібліотеку у Велеграді, влаштувати виклади i курси.

Третій конгрес Велеградський (1911 рік) відзначився неорганізованістю та хаотичністю. Очевидно, що причин на це було декілька: 1) відсутність митрополита Шептицького; 2) цілковита відсутність «Православних, яким агітация «Нового времени» i т.п. загородила дорогу до Велеграду» [Крип'якевич П. Третий конгрес велеградський // Нива.- 1911.- № 16-17.- С. 536]. Саме тому панівною на конгресі була чеська делегація.

Більшість програмних виступів відмінили 3 приводу відсутності доповідачів, а решту присутніх свої виступи скорочували на вимогу делегатів (як-ось виступ о. Николая Малиняка) або взагалі відмовлялись виступати (о. Пальмірі), мотивуючи вузькою спеціальністю теми. Дебати велись в основному навколо новітньої російської богословської літератури, яка перебуває під впливом протестантизму, а щодо практичних заходів стосовно реалізації ідеї унії на Сході, то було запропоновано перекласти акти Велеградських конгресів на російську та інші слов'янські мови та переслати всім східним християнам. В цілому ж третій конгрес проходив мляво і невиразно, якихось резонансів в світовій пресі не викликав, і тому передбачення о. П.Крип'якевича, шо «такий конгрес не може знидіти і упасти, але що з того діла конче щось мусить бути - і єсли не відразу сполученє церквей, то по крайній мірі таке підготованє сего святого діла, що потому до самого сполучення лише оден крок зістане» [Там само.- С. 537], викликало мало ентузіазму. 
Після восьмирічної перерви у 1921 році (5-7 серпня) було скликано організаційну нараду у Велеграді. Причиною такого великого інтервалу у часі була Перша світова війна. Ця ж причина була головною підставою для зміни у ході нарад: переважна більшість виступів мали чисто інформативний характер, адже відносини після війни змінилися, повстали нові державні утворення, які ще не встигли зав'язати між собою стосунки, виникли нові конфлікти релігійні і національні, а відтак і нові шляхи до можливого церковного поєднання. На наради прибули представники Підкарпатської Русі, України, Польщі, Югославії, Росії, Франції і Бельгії. Зі слав'янських земель лише болгари і білоруси не мали своїх представників. У виступах йшлося про нову церковно-релігійну ситуацію в Югославії, Болгарії, Словаччині, на Підкарпатській Русі та в Пряшівській єпархії. Великий резонанс викликав виступ о. Урбана «О polozeniu katolicyzmu w Polsce», зокрема його зауваги щодо «Polonia orientale» - так він назвав українські і білоруські землі, які Польща отримала на основі Ризького миру. На думку о. Урбана, серед населення тих земель відсутнє прагнення до унії чи навернення до римо-католицької церкви. Поляки хочуть зробити 3 тих провінцій автокефальну православну церкву i заключити конкордат 3 Царгородським патріархатом; стосовно запровадження католицизму слов'янського обряду, то така форма поєднання буде постійною причиною конфліктів, як-от у «Poloni-ï minor-ній» (Галичині). Так вважав доповідач. Крім того, пропонується нове вирішення протистояння римо- і греко-католицького кліру - біритуальність (щоб кожен священик і єпископ були римокатолицького i греко-католицького обряду) - «щоб міг по потребі відправляти богослуження в тому обряді, якого забажає населення, котре вертає до єдности» [Хомин Петро. Уніоністичні наради на Велеграді // Нива.- № 10.- С. 287].

Багато виступів стосувались колись єдиної Російської православної церкви. Це і виступ о. Домініка Трчка «Унія на Україні», i М.д’Ербіні «De Russis in emigratione», i д-ра Терсеглява «О России». У результаті цих виступів було визначено два принципи, якими слід керуватись при майбутній уніоністичній праці: «1) veritas, до котрої маємо притягати православних; 2) vera charitas, 3 котрою маємо приходити до православних» [Там само.- С. 290]. Крім визначення принципів діяльності, було затверджено ряд практичних пропозицій на майбутнє, зокрема:

- звернутись до Святого Престолу, щоб той затвердив і доручив «Апостольство Святих Кирила і Мефодія» всім слов'янам;

- прохати Апостольський Престол, щоб звернувся до всіх слов'ян iз спеціальною енциклікою про унію; 
- у католицьких духовних семінаріях запровадити вивчення Східного обряду;

- в якомусь західному католицькому університеті заснувати слов'янську кафедру.

Підсумовуючи, можна сказати, що наради у Велеграді, які відбулися в 1921 році, «розкрили образ релігійного життя слав'янських народів, подали много нових ідей та начеркнули много плянів, котрі будуть основою для найблизшого уніоністичного з'їзду» [Там само.- С. 291].

Цікавими моментами наступної Велеградської наради була відсутність польських делегатів та науковий рівень дебатів. Головне питання, яке обговорювалось - догмат про непомильність папи оскільки, «коли папа Лев XIII запросив своєю енциклікою Praeclara gratulationis (1894) Схід до переговорів о з'єдиненню церков, патріарх царгородський Антим VII відкинув се предложення, мотивуючи його тим, що наука римської церкви о приматі $є$ непоборимою перепоною злуки» [Сліпий Й. На Велеграді (6-9 серпня 1922 року) // Нива.- 1922.- № 10.- С. 339]. Можливо саме тому учасники наради вдались в глибокі богословські нюанси, доводячи, що непомильність папи у справах віри підтримує єдність церкви (о. Грівець, о. Спачіль, о. Ціпак, о. Виковкаль, д-р Фішер-Кольбрі, проф. д-р Гаджега та ін.).

Лише на 4-му засідання розпочалось обговорення справ церковного життя, зокрема «про «Ческо-Словацку релігійну секту», «Обряди в життю церкви» - говорив о. Вєрховський, а о. Зорвал-Карпаті - про «Ріжницю між Східною і Західною церквою після нового кодексу».

Як завжди, значне місце в дебатах відведене проблемі Російської церкви: переслідування іï більшовиками, організація «Вольної Академії Духовної в Москві і Петербурзі» (викладач Глубоковський); виникнення «Живої Церкви» на чолі 3 Антоном Храповицьким; арешт Тихона i митрополита Веніаміна; діяльність ліквідаційного комітету культу. Бурхливо обговорювалась i прозелітична поведінка поляків переслідування унії, спроби запровадження біритуалізму. В результаті наукових дебатів та обговорень було прийнято ряд резолюцій, зокрема: 1) «бачучи перепону злуки церков, яку робить примат і непомильність папи, вважає конечним ясне і недвозначне представлення тої правди віри в теології з увзглядненням однак способу думання орієнталів» [Там само.С. 400]. Відлунням дискусій була постанова про обряд, який «є великої ваги в духовім, культурнім і суспільнім життю народа... Клір бажає, щоб усі східні церкви заховали свій обряд» [п. 4]. Щодо практичних заходів, то вони радше мали інформативний характер: пропозиції о. Спачілю та о. 
Кахніку написати теологічні трактати про «науку церковну нез'єдинених та про апологію католицтва Святого Кирила і Мефодія на Сході і Святого Володимира, Ольги, Бориса і Гліба на Заході» [п. 2]. Найкращою формою просування унії на схід було визнано «харитативну дорогу».

Учасник наступного Велеградського конгресу засвідчує, що офіційна присутність папського нунція в Празі (перший раз від часу існування конгресів) i делегата чехословацького міністерства закордонних справ додали конгресу авторитету та ваги. Участь брали представники різних націй (іспанці, французи, англійці, бельгійці, німці, чехи, словаки, українці, руські хорвати, серби, словени, болгари, поляки, італійці, греки і румуни) - разом 300 делегатів, 3 них 20 єпископів. «Негативно позначилась на ході конгресу відсутність архиєпископа д-ра Стояна та високопреосвященного митрополита Шептицького ( його і Боцяна католицька Польща на конгрес не пустила» [О. Хомин Петро. Уніоністичний конгрес на Велеграді.- Нива.- 1924.- № 9.- С. 309]. Від православних росіян на еміграції прийшла привітальна телеграма від протоієрея Сергія Булгакова 3 Парижа, iі підписали також відомі російські філософи: Карташов, Трубецькой, Безобразов та інші. У своїй телеграмі вони вітають «діло з'єднання віри і любови та вказують на римський централізм як одиноку перепону єдності...» [Там само.- С. 311]. 3 СРСР представників ієрархії не було. 3 доповідями виступали: о. Грівец 3 Любляни, о. Гаджега з Ужгороду «Теперішні погляди нез'єдинених на церкву і прінціп єдності в ній» та Альфред Фусс «Культурне значіння Унії». Найбільший резонанс викликали реферати о. Гліба Верховського «Авторитет патріярхатів 3 догматичного, історичного i церковноправного становища і його відношення до теперішнього стану церковної єдности» та «Соціальне і релігійне положення російської еміграції у відношенню до квестії з'єдинення». Духовник російської католицької громади в Празі заявив: «Католицький Схід має стати для римської церкви середником з'єдинення цілого Сходу з Римом, тому поручає, щоби латинських месіонерів... (було - Н.М.) підчинено юрисдикції східно-католицького єпископства» [Там само.- С. 310]. Щодо еміграції, то о. Г.Верховський об'єктивно ствердив, що в середовищі емігрантів домінує «велика любов і прив'язання до православ'я, ... до католицизму упереджені, не довіряють навіть католицькій харитативній акції..., місіонарство виводить їх з рівноваги, тому ніколи не вільно говорити, що православіє - це кривовіріє чи розкол» [Там само]. Такий неординарний виступ спровокував гостру полеміку. Поляки вважали себе ображеними, про що заявив єпископ Пшездзєцкі. 
Слабка сторона Велеградських конгресів - їхня виняткова теоретичність і невміння орієнтуватися в ситуації. Забагато уваги на них приділялось Росії, залишаючи на узбіччі справи ближчі і легші для залагодження. Мова йде про колишні уніатські території, що тепер опинилися в католицькій Польщі, «котра чваниться, що привернути їх назад до єдности з Апостольським престолом, це iï dzejowe poslannictwo» [Там само.- С. 311]. Не розглянув конгрес і загрозливого розповсюдження православ'я у Чехо-Словаччині. В цілому конгрес так і не вийшов за рамки теоретичних міркувань. Із-за відсутності православного духовенства не було можливості розпочати якісь вступні незобов'язуючі переговори.

Поступово панівну роль на Велеградських з'їздах захопили представники католицького клиру. Згідно офіційної позиції, уніатизм як метод поєднання не виправдав себе 3 історичної точки зору, тому уніатські церкви, як продукт невдалого експерименту, не можуть займатися наверненням своїх східних сусідів - православних. Свого апогею така позиція католиків сягнула на п'ятому з'їзді, коли було заборонено відправляти глаголитську службу Божу, і найголовніше представникам уніатських церков не дозволили виступати з доповідями. Свої реферати на з'їзді вже зачитували лише католики. Доктор Дорожинський, учасник з'їзду, з обуренням підсумовує весь хід конгресу: «Одна річ таки дуже наглядно змінилася в Велеградівських Конгресах змінилися ролі: перед війною власно ми, галицькі уніати, виступали на тих конгресах якнайбілыше покликані практичні подвижники унії, тепер у тій ролі виступають ті, котрі перед війною й не брали участи в тих конгресах - поляки. Латинський (польський) єпископ (Пшездзєцький) реферує про успіхи уніонної акції між нашим народом» [Дорожинський О. 3 Велеградського з’їзду // Нива.- 1927.- № 7-8.- С. 300].

Зрозумівши свої помилки, представники католицького кліру вирішили їх виправити на наступному з'їзді у 1932 році. На цей раз підготовка та проведення з'їзду грунтовно висвітлювалась в пресі. Папа Пій XI особисто затверджував програму конгресу, який мав розглядати такі питання: «квестія християнської віри 3 боку догматичного, історичного i літургічного (з особливим увзглядненням науки про містичне тіло Христове та питання про вселенські собори)» [Хомин П. На Велеграді // Нива.- 1932.- № 8.- С. 284]. Як стверджувала L'Osservatore Romana, «цьогорічний конгрес перевершив усі дотеперішні - добором рефератів, якістю та кількістю учасників, участю православних і... великим пієтизмом до церковного сходу» [Цит. за: Церковні події // Нива.- 1932.- № 9.- С. 305]. Попри таку помпезність та пишномовність, 
конкретних результатів з'їд не досягнув. Його резолюції не відрізняються від Велеградських резолюцій 10-ти та й 20-ти річної давності. Єдиним новим моментом був пункт про засудження антирелігійної політики білышовиків.

Останній, сьомий Велеградський з'їзд відзначався найбільшою пишністю.

Попри те, що за правилом конгрес мав відбуватись кожні три роки, замість 1935 засідання перенесли на 1936, ювілейний - в честь 1050-ліття смерті святого Мефодія. Саме ювілей і визначив тематику нарад - особи обох Святих Братів, їхня діяльність, наукова спадщина, укладена ними Літургія.

Організацією конгресу займалось чеське духовенство на чолі 3 Оломоуцьким єпископом; саме 3 їхньої ініціативи було відокремлено виступи теологів та юристів, якщо перші в основному висвітлювали діяльність Святих Братів, то на засіданнях юристів йшлося в основному про особливості східного та західного церковного права. В атмосфері ейфорії було вирішено проголосити ювілейним i наступний конгрес: «Найближчий конгрес має відбутись в 1939 році в 500-ту річницю флорентійського собору» [Хомин П. Ювілейний Велеградський конгрес // Нива.- 1936.- № 9.- С. 292]. Резолюції свідчать про намагання перевести діяльність конгресу в конкретно-практичну площину: в руслі унійної діяльності та при підготовці наступного конгресу «1) мають розглядатися питання 3 душпастирської практики; 2) в рефератах - звіт 3 нез'єдиненої Церкви на еміграції і в Росії; 3) не тільки академічні питання, а й пекучі актуальні квестії з'єдинення церков...; 7) у всіх слов'янських семінаріях основати апостолят Святих Кирила i Мефодія; 8) конгрес прохає Апостольський Престол, щоб 14.02. і 6.04., дні смерті Кирила і Мефодія, були визнані як свята" [Там само].

Очевидно, що учасники конгресу не могли передбачити, що через два роки ситуація в Європі кардинально зміниться. У 1938 році завдяки так званій мюнхенській змові Чехословаччина перестане існувати. Світ стояв на порозі нової світової війни. У лабіринтах політичних інтриг та домовленостей уніатські церкви і спроби місійно-харитативної діяльності зійшли з порядку денного. Європу чекала Друга світова війна, а східні католицькі церкви - нові важкі випробування. 